\title{
Volatile Financial Markets and the Speculator
}

\author{
Paul Davidson ${ }^{1}$
}

\author{
This paper was given as the Economic Issues Lecture to the \\ Royal Economic Society Annual Conference, Warwick, England, April 1998
}

\section{Abstract}

In recent years it has become fashionable to argue for a tax on financial transactions in order to reduce the volatility of financial markets. In the USA, however, the volatility of the New York and American Stock Exchanges has declined, relative to that of the over-the-counter market, since the reduction in commissions. We argue here that what one expects from putting 'sand in the wheels' of financial activity depends upon how one explains the existence of speculative activity and that this depends upon whether or not one accepts the ergodic principle. We also argue that it is bandwagon effects and not white noise variance that causes problems in financial markets and that the solution for this must involve the creation of a market maker prepared to 'lean into the wind' when markets show signs of departing from fundamentals.

\section{Introduction}

New Keynesians Joseph Stiglitz (1989) and Lawrence Summers (Summers and Summers 1989), following the lead of Old Keynesian James Tobin $(1974,1995)$, have argued that an ad valorem tax on financial market transactions is socially desirable in that it will reduce the observed volatility in our 'superefficient financial markets'. All of these Keynesians claim that Keynes initiated the recommendation for a universal financial transactions tax as a socially desirable policy.

Keynes (1936, p.159) did argue that speculation can have adverse effects on real economic outcomes. Keynes suggested that public access to financial markets should be, like access to casinos, 'inaccessible and expensive'. Indeed, after the collapse of the Wall Street stock market in the 1930s, Keynes (1936, p. 160) suggested that the 'introduction of a substantial Government transfer tax on all transactions might prove the most serviceable reform available, with a view to mitigating the dominance of speculation over enterprise in the United States'.

A recent study by Jones and Seguin (1997) (hereafter J-S), however, appears to conflict with this 'Keynesian' claim that transaction taxes reduce volatility. J-S note that on May 1, 1975 fixed commissions on the New York Stock Exchange (NYSE) and American Stock Exchange (AMEX) were uniformly changed (lowered $\mathrm{d}^{2}$ ) to negotiated commissions, while the commission structure on all over-the counter (OTC) transactions in the United States were unchanged. Using daily data for one year before and one year after the change in commission basis, J-S (1997) examined daily volatility in five sample portfolios sorted by size ${ }^{3}$. A total of 1872 securities traded on NYSE and AMEX and the OTC were studied where the OTC portfolios were used as a 
'control sample' (J-S, 1997, p. 729). J-S calculated cross sectional mean market values for each portfolio and daily return standard deviations (their measure of volatility). J-S (1997, p. 729) concluded that their 'empirical evidence uniformly reject the hypothesis that the abolition of [higher] fixed commissions increases volatility...we find a reduction in transactions costs is associated with a decline in ...volatility'4.

We may ask 'how can such eminent theorists as Old Keynesian Nobel Laureate Tobin, as well as New Keynesians potential Nobel Laureates Stiglitz and Summers, and even the old, original Keynesian, J M Keynes, apparently, be so wrong?' To comprehend the apparent difference between J-S's empirical results and the Keynesian claims we must inquire into how economists explain the existence of speculative activity on financial markets. We will see that one's explanation of the existence of speculative activity depends on the axiom invoked to explain how agents make decisions involving outcomes that will occur in the future. One obtains significantly different explanations regarding the effects of speculation and the efficiency of financial markets depending on whether one accepts or rejects the ergodic axiom.

\section{Ergodicity and efficient markets}

Efficient market theory claims that agents analyze past and present market data (i.e., price signals that are presumed to provide 'information' about future events) in forming rational expectations as a basis for making utility maximizing decisions. If agents take actions based on these rational expectations, then markets are efficient in that the resulting spot and forward price vector results in a welfare optimum.

Samuelson (1969, p. 184) has made the acceptance of the ergodic axiom the sine qua non of economics as a science. Following
Samuelson's ergodic edict, Lucas and Sargent (1981, pp. xi-xvi) made the ergodic axiom not only a necessary and sufficient condition for forming rational expectations but also a necessity for developing economics as an empirically based science ${ }^{5}$. In an ergodic system, estimates of today's objective probabilities calculated from an observed data set provide (statistically) reliable information about the conditional probability function that will govern future outcomes. The ergodic axiom is a necessary foundation for efficient market theorists to claim that (1) there exist real 'market fundamentals' that are immutable in the sense that they can not be changed by human action and (2) these fundamentals determine either the conditional probabilities of future outcomes ${ }^{6}$ (or a menu of all possible states of the world and possible contingencies).

\section{Stiglit, speculators, and efficient markets} In efficient market theory, agents gather information about fundamentals to calculate statistically reliable conditional probabilities regarding the future. Accordingly, the future is merely the statistical shadow of the past. If gathering this information is very costly, then there can be private return incentives for each agent to outrace others to calculate an actuarially reliable future. Stiglitz (1989, p. 103) states that beating the market 'affects how the pie is divided, but does not affect the size of the pie', since the size is determined by 'real' immutable parameters, the so-called 'fundamentals'. Future real returns of the underlying real assets are the inevitable outcomes pre-determined by today's fundamentals and unalterable by human activity. Of course, this information will inevitably reveal itself (at least in the long run) in determining the secular trend of financial market prices. By asserting that 'production, in every state of nature, in every 
contingency is precisely what it would have been had the information not been available', Stiglitz (1989, p.103) is implicitly arguing that the future is immutably determined by fundamentals. Stiglitz's efficient financial markets model is therefore firmly anchored on the ergodic axiom.

All Old and New Keynesians as well as all Classical economists accept the efficient market hypothesis as the applicable description of financial markets and therefore are invoking the ergodic axiom. One logically inevitable conclusion of the efficient market hypothesis is that, as Stiglitz (1989, pp. 1023) states, the most 'important social function' of financial markets is to correctly allocate capital among industries in accordance with retiable information about future rates of return determined by fundamentals?

Stiglitz (1989, pp. 105-7) claims that a small transactions tax has a strong deterrent effect primarily on short-term speculators ${ }^{8}$. The tax will not be a deterrent to long-term asset holders who are rational ${ }^{9}$ market participants and who "base their trading on fundamentals...and are willing to wait a long time to realize a retur' (Stiglitz, 1989, p. 105). Rational market participants therefore do not change their already optimal behavior if a transaction tax is imposed.

In Stiglitz's model, short-term traders consist of essentially two groups: 'The noise traders and those who live off them' (Stiglitz, 1989 , p. 106). Observed volatile asset price movements away from fundamentalsdetermined values are attributed primarily to the existence of 'noise traders', i.e., the speculators who mistakenly believe they know how the stock market works and therefore do not have to acquire the correct information regarding future outcomes from the fundamentals (Stiglitz, 1989, p. 105). Those rational traders who feed on these foolish noise traders ultimately return the market to its fundamental value. The 'mistaken belief of all speculators' that they can do better than the market by ignoring the fundamentals is Stiglitz's (1989, p.106) explanation of the horrendous speculative volatility that we observe in our world. Since "the turnover tax primarily affects the short-term [noise trader] speculator' (Stiglitz, 1989, p. 105) who is the creator of excessive volatility, a tax on such foolish speculators will save them from their own folly and save resources for society and is consequently socially desirable.

How can Stiglitz explain the centuries-long persistence of speculation observed in real world financial markets if the latter are efficient at weeding out those who make persistent errors? After all, for volatility to persist Stiglitz's analysis requires a permanent stream of short-term traders who 'are betting that they can do better than the market...based on the mistaken belief that (all!) speculators can do better than the average'10 (Stiglitz, 1989 , p. 106).

In developing his noise trader-as-fool argument, Stiglitz has cornered himself into a logical inconsistency that requires him to use a contradiction to try to extricate himself. Implicit in Stiglitz's model is that there is something strange and different about financial markets vis-a-vis product markets. Stiglitz (1989, p.102) accepts the argument that the imposition of a transaction tax in any product market will distort the Pareto-efficient price structure. Stiglitz argues that a similar tax in the financial markets, however, does not have such a deleterious propensity but rather 'such a tax may be beneficial' (Stiglitz, 1989 , p. 102). Since short-run speculation trading is attributed primarily to the action of fools ( noise traders), they interfere with the efficient capital allocation function of financial markets. The tax, by making it 
more costly for fools (as well as for all other mortals ${ }^{11}$ ) to engage in short-run financial market activity therefore improves the efficiency of financial markets.

If financial markets are efficient and immutable market fundamentals are the determinants of the future returns, then those irrational agents who make persistent errors will either become extinct via some Darwinian economic process, or they will survive only by learning how not to make persistent mistakes $^{12}$. Nevertheless, the pragmatist Stiglitz recognizes that after several centuries of significant volume of daily trades on financial markets - and daily trading volume has increased dramatically in the last two decades - speculation continues to exist and even increase. But how can persistently mistaken 'noise traders' continue to exist in an efficient market system where rational traders can feed off these fools?

To resolve this dilemma of the centuries old existence of speculation in financial markets, Stiglitz appeals to authority - the ultimate free market authority and successful circus impresario - P T Barnum. Stiglitz (1989, p. 106) misquotes Barnum's dictum 'There's a sucker born every minute'13 as 'There is a fool born every moment' and even incorrectly attributes this homily to one G T Barnum. Nevertheless, Stiglitz's appeal to Barnum's authority implies that society continues to produce, even in the long run, fools who irrationally believe they can beat the market.

Faced with the contradiction between the implications of the efficient market hypothesis where those who make persistent errors are eradicated and his attribution of volatile financial markets to the persistent existence of foolish market participants, Stiglitz has done the only 'rational' thing that a potential Nobel prize recipient can do. He ignores this logical inconsistency. Instead Stiglitz (1989, p. 106) buttresses his argument that 'irrationality is pervasive' by appealing to the facts that this ubiquitous, persistent irrationality exists even among Stiglitz's brightest economics students $^{14}$. If students at our most prestigious universities are such irrational dolts, then what can one expect of the average financial market participant bereft of exposure to any efficient market analysis?

Stiglitz either does not realize, or else he ignores the idea, that if centuries-long 'pervasive irrationality' is necessary for his explanation of financial market volatility, then logical consistency requires him to admit that irrationality can persist and be pervasive in all product markets ${ }^{15}$. If Barnum's homily that there is a sucker born every minute is a necessary condition for one's market model, then one must reject the orthodox argument that all markets involve efficient Darwinian processes that, at least in the long run, eradicate persistent error-making fools. If Barnum is correct (and he certainly understood the circus market), then orthodox theory can not claim that laissez-faire markets will maximize the welfare of the community, even in the long run. Pareto efficiency becomes a tale on a par with Aesop's fables. To provide an analysis of speculation and volatility, Stiglitz is throwing away both the classical bath water and the classical baby ${ }^{16}$.

Stiglitz's problem is that he has confused the logic of efficient financial market behaviour in an ergodic (logical) system with real world financial market behavior when agents know they are dealing with an uncertain (nonergodic) future ${ }^{17}$ (see below).

\section{Summers, Tobin, and super-efficient markets}

Lawrence Summers and his wife Victoria (Summers and Summers (hereafter S-S) 1989) advocate a financial transaction tax to reduce financial market volatility (see by S-S, 1989, p. 216). S-S claim that the 'ultimate social 
functions [of financial markets are] spreading [probabilistic] risks, guiding the investment of scarce capital, and processing and disseminating the information possessed by diverse traders'. S-S endorse the logic of efficient market theory when they claim that real world 'stock prices will always reflect fundamental values .... The logic of efficient markets is compelling' (S-S, 1989, p. 166). Using the same micro-foundations as Stiglitz to explain financial market volatility, S-S $(1989$, p. 170$)$ also attribute volatility to the persistence of foolish noise traders who are 'trading on the basis of something other than information about fundamental values'.

Exacerbating this impact of fools on market values, S-S add a 'positive feedback' trading strategy (S-S, 1989, p. 171) by rational traders who know about fundamentals and therefore know that noise traders are fools. These positive feedback traders, however, see their self-interest is to go with the flow. They trade often in the short-term (using strategies like stop-loss orders) to insure themselves of short-term gains rather than swimming against the tide to make the inevitable long-run arbitrage profit resulting when spot prices move away from 'fundamental values'.

S-S (1989, p. 165) claim that there 'are strong economic efficiency arguments in support of some kind of [transactions tax]...that throws "sand into the gears" to use Tobin's phrase, of our excessive wellfunctioning (super-efficient?) financial markets. The efficiency benefits from curbing speculation are likely to exceed any costs of reduced liquidity or increased costs of capital.' S-S claim (p. 166) 'Excessive speculation that increases volatility ... create[s] rather than reduce[s] risk, distort[s] the allocation of investment, and limit[s] information contents of asset prices'.

Finally, perhaps the best known advocate of financial transaction taxes is Nobel prize laureate James Tobin (1974). In 1995, for example, Eichengreen, Tobin, and Wyplosz (1995, p. 164) (hereafter ETW) forcefully argued that short-term volatility in foreign exchange markets due to speculation can have 'real economic consequences devastating for particular sectors and whole economies'. To constrain 'speculative behaviour... they [ETW] propose a global transaction tax...to discourage short-term round tripping' (Greenaway, 1995, p. 160) thereby putting 'grains of sand' into the operation of what they called 'super efficient financial markets' (ETW, 1995, p.164).

\section{Keynes, speculation and liquid financial markets}

Keynes's (1936, pp. 161-3) explanation of the existence of speculative activity requires rejecting the restrictive ergodic axiom. Keynes argued that, at any point of time, the future is uncertain in the sense that the actuarial profit or a reliable mathematically based expectation of gain calculated in accordance with existing probabilities can not be obtained from any existing data set. In 1937, Keynes emphasized the difference between his 'general theory' and classical orthodoxy. In the latter,

...[f]acts and expectations were assumed to be given in a definite form; and risks... were supposed to be capable of an exact actuarial computation. The calculus of probability...was supposed capable of reducing uncertainty to the same calculable state as that of certainty itself....I accuse the classical economic theory of being itself one of these pretty, polite techniques which tries to deal with the present by abstracting from the fact that we know very little about the future.... [a classical 
economist] has overlooked the precise nature of the difference which his abstraction makes between theory and practice, and the character of the fallacies into which he is likely to be lead (Keynes, 1937, pp.112-5).

In Keynes's analysis, therefore, even if 'fundamentals' exist today and even if a data set permits one to estimate today's (presumed to exist) objective conditional probability distribution, such calculations do not form a reliable base for forecasting the future. In other words, today's conditional objective probabilities are not a reliable actuarial guide to the future.

Keynes's description of uncertainty matches technically what mathematical statisticians call a nonergodic stochastic system. Consequently, in Keynes's General Theory, financial markets cannot be presumed to be efficient. In a nonergodic system, one can never expect whatever data set exists today to provide a reliable guide to future outcomes. In such a world, the primary function of financial markets is to provide liquidity. This liquidity function involves the ability to buy and resell assets in a well-organized, orderly market in order to obtain the medium of contractual settlement to meet one's nominal contractual liabilities when they come due.

Peter Bernstein (1998) has properly argued 'An efficient market is a market without liquidity'. The ability to maintain one's liquidity may be important to individuals but it is not an important social function if markets are efficient ${ }^{18}$. Logical consistency for those claiming financial market efficiency requires the presumption that individual agents can also plan their future spending on goods and services efficiently by buying and selling financial assets whose maturity dates match the individual's life-cycle spending pattern stream vis-a-vis the individual's life- cycle income pattern stream (e.g., as assumed in overlapping generation models). Sudden liquidity needs, to meet uncertain, unpredictable future contractual obligations when they come due, or cases where issuers of financial assets can not meet their contractual obligation to pay interest or redeem at maturity date, have no role to play in efficient market theory.

If, however, agents in one's model believe their world is uncertain (nonergodic) as Keynes and later Hicks (1977, p. vii) claim, then decision makers 'know' that what others call today's 'fundamentals' do not provide a statistically reliable guide to the future. In such a world, protecting the value of one's liquid portfolio against unforeseen and unforeseeable changes in financial market values becomes an important economic activity. Accordingly, portfolio fund managers must, in an instant, conjecture how other market players will interpret a news event occurring anywhere in the world.

In a nonergodic system, one is always uncertain about future market valuations. Now a practical theory of the future [market valuation is]...based on a flimsy foundation. It is subject to sudden and violent changes. The practice of calmness and immobility, of certainty and security, suddenly breaks down. New fears and hopes will, without warning, take charge of human conduct. The forces of disillusion may suddenly impose a new conventional basis of valuation' (Keynes, 1937 , pp. 114-5). In a world of instant communication, any event occurring in the world can set off rapid changes in subjective evaluation of the market value of one's portfolio. Speculation about the psychology of other market players can result in lemminglike behavior which can become selfreinforcing and self-justifying. In a nonergodic system, if enough agents possess the same 'incorrect' expectations (to use 
Stiglitz's phrase), the result can be that these faulty expectations actually create future outcomes (cf. Arestis and Sawyer, 1998, pp. 188-9). The first 'irrational' lemmings to hit the ocean of liquidity may not drown. They may survive and even thrive to have more irrational expectations and lead more lemming-leaps into liquidity in the future.

\section{Keynes, liquid financial markets and the $J$-S findings}

In a nonergodic world, the primary function of financial markets is to furnish liquidity by providing an orderly, well organized environment where financial assets can be readily resold for cash while the essential properties of the underlying real capital assets prevent them from producing the attribute of liquidity $^{19}$. In so doing, financial markets promote the separation of ownership and management (Keynes, 1936, pp. 150-1) (Davidson, 1972, pp. 61-9) (Bernstein, 1998). In the absence of a liquid financial market ' $[\mathrm{t}]$ here is no object in frequently attempting to revalue an investment to which we are committed' (Keynes, 1936, p. 151). If capital markets were completely illiquid then there would be no separation of ownership and control. Once some volume of real investment was committed, the owners would have an incentive to use the existing facilities in the best possible way no matter what unforeseen circumstances might arise over the life of plant and equipment. Perhaps then capital markets might behave more like the efficient markets of mainstream theory.

Since Keynes's analysis of the operations of an entrepreneurial money-using market system presumes an uncertain (nonergodic) environment, in his General Theory the primary function of financial markets is to provide liquidity. Under circumstances where bullish sentiment dominates, liquid financial markets can encourage savers to provide readily the funding that encourages entrepreneurial investors to spend sums on new investment projects that far exceed their current incomes. Under other circumstances where the bear position is overriding, an excessive desire to maintain one's liquidity can develop that may impede the production of new investment capital even when real resources are idle and therefore readily available to produce new real capital goods. Too great a demand for liquidity can prevent 'saved' (i.e., unutilized) real resources from being employed in the production of investment goods.

Unlike Old and New Keynesians, Keynes explicitly recognized that the introduction of sand in the wheels of liquidity-providing financial markets via a transactions tax is a double-edged sword. Keynes (1936, p. 160) noted that a financial transactions tax "brings us up against a dilemma, and shows us how the liquidity of investment markets often facilitates, though it sometimes impedes, the course of new investment'.

Keynes explained the circumstances that create price stability in financial markets when he noted that 'it is interesting that [asset price] stability $\ldots$ and its sensitiveness... should be so dependent on the existence of a variety of opinion about what is uncertain. Best of all that we should know the future. But if not, then, if we are to control the activity of the economic system ... it is important that opinions differ' (Keynes, 1936, p. 172). In other words, the 'best of all' possible worlds for financial market stability would be an ergodic system where the future can be known with statistical reliability. Then the future can be reduced to actuarial certainty, i.e., 'we should know the future' and market efficiency would be assured as long as agents operated in their 'known' self- 
interest.

If the system is nonergodic, however, then actuarial certainty and the possibility of rational probabilistic risk spreading - which S$S$ claim is an essential aspect of efficient markets - is impossible. Accordingly, the second best solution, and the only one available for nonergodic systems, is to encourage a substantial number of market participants to hold continuously differing expectations about the future so that any small upward change in the market price brings about a significant bear reaction, while any slight downturn induces a bullish reaction. The result will be to maintain spot financial market (resale) price trend stability over time and therefore the market will maintain a high degree of liquidity. In a nonergodic environment, the expectations of either the bulls or the bears can not be described as either rational (in the Lucas sense) or ex ante correct. Accordingly, market stability requires a continuous (and dense) spectrum of bull and bear expectations - the more participants in this spectrum, the less, ceteris paribus, volatility.

Old and New Keynesians conflate the concept of volume with that of volatility when they argue that a transaction tax will reduce the number of market participants (especially the short-term traders), and therefore assures less volatility. It is this confusion that makes these Keynesian claims inconsistent with the empirical findings that transaction taxes and volatility are positively related. The J-S empirical findings, however, are consistent with Keynes's General Theory analysis where the larger the number of market participants with differing opinions, at any point of time, ceteris paribus, the more stable the market price of traded liquid assets. The more stable the price in financial markets the greater the degree of liquidity of the asset $\mathrm{t}^{20}$. (Although in his published papers using nonstochastic modelling, Hicks (1979, p.113n) associates uncertainty and Keynes's liquidity analysis with a violation of the ordering axiom, in a private letter to me, he indicates that he should have labelled his 'own point of view as nonergodic'21.)

\section{Ergodicity, efficient markets, and the $J-S$ findings}

For those who proclaim the efficiency of financial markets, logical consistency requires them to claim that the 'observed' secular trend of financial market prices (typically measured by a moving average) are determined by immutable (ergodic) real sector fundamentals ${ }^{22}$. Presumably these fundamentals are 'dynamic' in the sense of Sargent (1993, p. 26-7) that the probability 'of how likely it is' to have a future regime change, i.e., a change in the fundamentals, must be already encapsulated in the information existing at the initial instant for rational expectations to be formed. If one does not presume that every possible future regime change is already nested in existing probabilistic information about every contingency in every state of the world, then financial markets can not be claimed to be efficient as today's real capital allocations can result in future possible egregious costly errors $^{23}$.

By claiming that financial markets are not only efficient but are super-efficient, Tobin and New Keynesians are accepting the ergodic axiom in spades. Consequently, the measured daily variance around the statistical time series (moving) average that is determined by fundamentals, can only be attributed to 'white noise'. But in an ergodic stochastic system, anything that increases the number of participants, increases the size of the sample at each point of time and therefore must decrease the measured "white noise" variance around the daily mean. 
The only exception to this rule would be if the additional sample observations were being drawn from a different statistical universe, as for instance if a significant proportion of additional participants behave in a different manner than those observed in the original sample. Thus, if increased volume is associated with a plethora of similar thinking 'irrational' participants suddenly entering the market previously dominated by 'rational' beings, then the market might exhibit what central banker Alan Greenspan labelled 'irrational exuberance'. In this case, provided the 'rational' traders did not change their behavior, one might expect a sudden short-run widening of variance despite the larger observed volume per day. In other words, the measured variance might increase in the shortrun even in an hypothetical Stiglitz efficient market while the rational traders enjoyed the feast. But in the longer-run, the larger the number of participants in an efficient market, the smaller the variance, since variance has the property of being inversely related to the size of a random unbiased sample. In the long-run, as irrational traders are made extinct by an efficient market, the remaining sample will be unbiased. Only rational traders can survive.

Reducing transactions costs is equivalent to lowering the admission price for participation. If the system is ergodic then the entry of more traders, by definition, increases the breadth of the market. In statistical terms, this implies that as the size of the sample drawn each day from a given universe increases, the variance declines. Tobin, Summers, and Stiglitz are excellent econometricians and should have recognized that their acceptance of the logic of efficient market theory and the use of a white noise analogy implies that raising transactions costs must, ceteris paribus, increase variance by reducing the size of the sample (volume) at any point of time.

If fundamentals do determine the future secular trend in the financial markets' asset spot prices, then it logically follows that speculators who have 'the object of securing profit from knowing better than the market what the future will bring forth' (Keynes, 1936, p.170) are irrational fools who in the long run must lose their shirts. Every (rational?) decision maker 'knows' that financial price movements (i.e., volatility around the fundamental value) are merely a random walk. There is, therefore, no rational role for the speculative motive in any model that presumes 'rational' self-interest financial behavior! And that is why Stiglitz and Summers must rely on the continuous generation of pervasive and persistent irrational fools to explain secular excessive volatility.

\section{Are real capital allocation decisions efficient?}

Keynes (1936, p. 158) defines enterprise as 'the activity of forecasting the prospective yield of assets over their whole life' and the marginal efficiency of capital as a 'series of annuities given by the returns expected from the capital-asset during its life' (Keynes, 1936, p. 135 Italics added). Do these definitions imply entrepreneurs make decisions 'as if' they are in an ergodic system?

Not really. Although Keynes uses terms such as 'forecasting' and 'the expectation of yield' in his discussion of entrepreneurial investment decisions, Keynes (1936, pp. 14950) warns the reader that

Our knowledge of the factors which will govern the yield of an investment some years hence is usually very slight and often 
negligible.... In fact, those who seriously attempt to make any such estimate are often so much in the minority that their behaviour does not govern the market.... if human nature felt no temptation to take a chance, no satisfaction (profit apart) in constructing a factory, a railway, a mine or a farm, there might not be much investment merely as the result of cold calculation.

Moreover, an entrepreneurial 'decision to do something positive can only be taken as a result of animal spirits... and not of the outcome of the weighted average of quantitative benefits multiplied by quantitative probabilities' (Keynes, 1936, p.161). In other words, the expectations embodied in entrepreneurial investment allocationdecisions can not be the rational expectations that result in the efficient allocation of capital decisions described by New Classical and New Keynesian economists. Enterprise, in the real world we inhabit, is unlikely to mimic the allocation of capital implied in an ergodic system.

Neither real-world financial markets nor capital goods markets are, in classical terms, efficient ${ }^{24}$. Keynes clearly and completely rejected the special and restrictive ergodic axiom as a basis of explaining behavior by investors in long-lived real capital goods formation as well as saver-participants in financial markets who are making liquid portfolio allocation choices. In rejecting the need for the restrictive ergodic axiom, Keynes placed the burden on those who make use of such a highly special assumption to justify it, while those who reject any special restrictive axiom are not required to prove the general negative (Keynes, 1937, p. 109).

Despite their willingness to accept the efficiency of financial markets micropresumptions as an unquestioned universal truth, the common sense of Tobin and his
New Keynesian followers regarding realworld financial markets can not help but break into their logical models - with injury to their logical consistency. Old and New Classical economists do not suffer from such logical problems. Like 'Ricardo [Friedman and Lucas] offer us the supreme intellectual achievement, unattainable by weaker [mainstream Keynesian] spirits, of adopting a hypothetical world remote from experience as though it was the world of experience and then living in it consistently' (Keynes, 1936, p. 192)

When Tobin and others advocate a universal transactions tax to impede distuptive speculation, they are recognizing that the expectations that drive spot financial market prices are not rational. Rather, real-world financial market prices involve, as Keynes noted, a conventional valuation based on the psychological confidence we have of forecasts that we 'know' can not be statistically reliable $^{25}$ (Keynes, 1936, p. 148). Valuations based on forecasting market psychology can, at times, create speculative whirlpools.

\section{Nonergodicity, speculative whirlpools and bandwagons}

Although Keynes did not use the ergodicnonergodic terminology, Keynes utilized this concept when he claimed (1973, p.308) that Tinbergen's (econometric) method 'was invalid [because]...the economic environment is not homogeneous over a period of time (perhaps because non statistical factors are relevant)', i.e., economic time series are nonstationary. Since nonstationarity is a sufficient condition for nonergodicity, Keynes's concept of financial and economic uncertainty implies nonergodicity. More recently, Solow has endorsed Keynes's position. Solow wrote that 'much of what we observe cannot be treated as the realization of a stationary stochastic process without straining credulity' (Solow, 
1985, p. 328). This implies a recognition that important economic data, that some call the fundamentals, are not generated by ergodic systems.

With his emphasis on uncertainty as the major force explaining the speculative demand for liquidity, Keynes (1936, pp. 148-51, 194209) had to reject the classical ergodic axiom of efficient market theory to explain market behavior. Consequently, using efficient market theory to explain speculation is, to Keynes and Post Keynesians, equivalent to relying on the axiom of parallel lines in a non Euclidean world to explain why 'in experience, straight lines apparently parallel often meet' (Keynes, 1936, p. 16). Rebuking these lines for crashing into each other is similar to relying on persistent irrational behavior of noise traders to explain market volatility. Both are useless homilies.

Keynes emphasized that asset liquidity requires market broadness to permit each individual to sleep easily assured that savings vehicles are a good store of general purchasing power. The empirical results of $\mathrm{J}$ S $(1997$, p. 736$)$ demonstrate that by reducing transactions costs one enhances daily liquidity and stability provided certain conditions are met. These provisos are (1) both the bulls and bears are widely represented among the additional participants and (2) within each of these categories there are a continuum of divergent views among individuals as to when to change from the bull to bear position and vice versa. To the extent that a reduction in transactions costs increases the number of participants in both the bull and bear positions, then, ceteris paribus, there is more likely to be a denser continuum and therefore less moment by moment or daily variability. In such circumstances, as Keynes noted, speculation becomes mere bubbles on the steady stream of enterprise.
If, at any point of time, however, there is a sudden swing to a bandwagon consensus, i.e, there is abruptly a lack of broad market participants with differing (not rational) expectations about the future, then there can be a rapid swing in market prices. To prevent this volatility due to private sector bandwagon actions what is required is a market maker institution with sufficient resources to assure market price stability. The market maker must announce that it will swim against any developing consensus view regarding a change in market psychology. This announcement by the market maker must be deemed credible by market participants.

A bandwagon effect occurs when a consensus view suddenly congeals regarding the possibility of a severe change in the future spot market price of financial assets. The bandwagon concept implies that there suddenly appears a preponderance of participants only on one side of the market (whether it be in the bull or bear position). In the absence of a market maker with sufficient financial asset resources to stem the bandwagon tide, "enterprise becomes the bubble on a whirlpool of speculation' (Keynes, 1936, p. 159). It is 'bandwagon' movements in financial markets and not daily white noise variance that causes problems in financial markets. The resultant change in the secular trend of financial market prices change due to bandwagons can have 'real economic consequences devastating for particular sectors and whole economies' (ETW, 1995, p. 164).

Keynes's whirlpool of speculation analogy is not a description of a daily (or hourly?) volatility around a long-term stable secular trend as measured by J-S in terms of daily return standard deviation. Rather disruptive speculation involves unpredictable sharp and profound changes in the ex post moving 
average secular trend due to anticipating market psychological swings. Even if there had been any 'bandwagon' changes in expectations during the year following May 1 , 1975, we should expect that the J-S empirical results would show less daily variance (volatility) in the NYSE and AMEX market portfolios vis-a-vis the 'control' OTC portfolios. Before May 1, 1975, the NYSE and AMEX markets were broader and deeper markets than the OTC market. The post- May 1, 1975 reduction in NYSE and AMEX transactions costs merely increase the broadness and depth of the NYSE and AMEX markets and, therefore reduced their daily variance more than in the OTC market.

\section{A policy implication: buffering conventional wisdom}

In a nonergodic world, Keynes insisted (1936, p. 152), the conventional wisdom is that market participants believe that the existing market valuation is correct. The market 'knows'

the existing state of affairs will continue indefinitely, except in so far as we have specific reasons to expect a change.... We are assuming, in effect, that the existing market valuation, however arrived at, is uniquely correct in relation to our existing knowledge..., though, philosophically speaking, it cannot be uniquely correct, since our existing knowledge does not provide a sufficient basis for a calculated mathematical expectation.

In other words, in the world of experience, conventional wisdom is that as long as it is expected that the psychology of the market is not changing there will be an inertia in market valuations. It then follows that any policy that involves reducing if not eliminating the possibility of disruptive speculation in financial markets must involve building institutions that assure market participants that the 'correct' market psychology is a belief in a persistent, stable (moving average) trend in market prices over time ${ }^{26}$.

If, for example, the market participants believe that there exists a market maker who can guarantee an unchanging spot market price (or changing only within very small boundaries) over time under preannounced and readily understood rules of the game in an orderly and well-organized market, then the existence of this creditable market maker will provide an anchor for "market psychology'. For participants to believe in the market maker's ability to maintain the target spot (resale) price, however, the market maker must have a 'sufficient' inventory of money and that item that is being sold in the relevant market. In our current foreign exchange market system, for example, this implies that the domestic monetary authority ${ }^{23}$ has creditability (and a sufficient inventory of foreign reserves or easy access to additional reserves) and has announced that it will use its reserves to maintain an orderly market at the 'proper' exchange rate ${ }^{28}$.

To prevent disruptive speculation in any specific market, therefore requires a buffer stock policy ${ }^{29}$ practised by a market maker. If the majority of market participants believe in the market maker's buffer stock approach, the only speculators that could exist would then be fools, i.e., a small group of offsetting bulls and bears, who disagree with the vast majority of market participants but whose actions can not affect market movements. Provided there is an effective buffer stock market maker, there should be no disruptive speculation and enterprise can continue at its current steady stream towards an unknown future.

Tobin's common sense led him to recognize that under the current financial market system there is always the possibility of disruptive 
whirlpools of speculation in the foreign exchange rate market that could cause devastating effects on the real economy. Yet Tobin's q-ratio analysis implicitly supports the view that investment markets efficiently allocate new capital. The numerator of the qratio represents a rational market's estimate of the present value of the prospective income of a real capital asset while the denominator represents the current nominal cost of producing new real capital goods. Consequently, logical consistency requires Tobin to support the q-ratios generated by freely mobile financial flows as proper. In his 'sands in the wheels' of efficient financial markets analysis, however, Tobin deserves kudos for his recognition of a serious real world problem of potential whirlpools of speculation.

\section{Conclusion: fixed exchange rates and one-way bets}

This paper has demonstrated that attributing volatility to the existence of noise traders, and therefore suggesting that transactions taxes will reduce volatility does not withstand either logical or empirical scrutiny. Nevertheless, I have supported Tobin's argument that freely flexible exchange rates can have disastrous real consequences. I have suggested that a policy of building a buffer stock foreign exchange rate market maker institution to fix (or at least constrain) price movements is socially desirable (See Davidson, 1994, pp. 263-83; 1997, pp. 6805).

Accordingly, if this audience has stuck with me thus far, let me deal with the conventional wisdom that argues that the institution of a fixed exchange rate by a governmental market maker ultimately always becomes a free oneway bet for private spectators when the exchange rate to be defended by the market maker chosen is no longer 'appropriate'. Under any conventional exchange rate system (whether it be fixed - even under a gold standard - or a flexible rate system), the conventional wisdom is that when a persistent deficit in the balance of payments occurs or is contractually imminent ${ }^{30}$, then it is the deficit nation that must take all the remedial action for it will otherwise run out of international liquidity. The nation experiencing a persistent international payments surplus is under no pressure to alleviate this international payments imbalance even though it has the liquidity and therefore the wherewithal to do so. The conventional wisdom 'knows' that the deficit nation does not have the liquidity to withstand a speculative attack - and that the surplus nation, being under no pressure, will not alleviate its trading partner's liquidity problem. These circumstances provide the conditions that make the free one-way bet possible.

If, however, speculators know that the rules of the game in foreign exchange markets require the surplus nation to bear a major responsibility for preventing disruptive speculation, then whatever fixed exchange rate that is agreed on in advance by the two nations will be the 'appropriate' one in the sense that private sector speculators' betting for a change in the exchange rate would always lose. Spot financial market price fixity can never produce a free one-way gain option for private sector speculators if the market maker has sufficient liquidity to dominate the market ${ }^{31}$.

Finally, it should be pointed out that fixing financial spot market prices does not necessarily imply a never-changing price. Rather fixity means that the market maker will permit the price to change only at a preannounced rate under preannounced specific rules of the game that kick-in if 
certain conditions should occur in the future.

\section{Endnotes}

1. University of Tennessee. I am grateful to Peter L Bernstein for some interesting electronic discussions that encouraged me to write this paper.

2. The introduction of negotiated commissions on the NYSE and AMEX 'instigated a permanent decline in commissions - regardless of the metric used, commissions on institutions fell between $31 \%$ and $44 \% \ldots$ [and for individuals] between $2 \%$ and $47 \%$ ' while volume increased substantially (J-S, 1997, p.730).

3. Each sample portfolio was based on outstanding market value of common equity (size) with sample 1 being largest size stocks and sample 5 being smallest size.

4. Using Swedish data, Umlauf (1993) also demonstrated that variance increased as a financial transactions tax rate increased.

5. While simultaneously, Lucas (1981, p. 563) admits that classical axioms are 'patently artificial'.

6. In stochastic models, this ergodic axiom presumes that objective and timeimmutable probability distributions exist. Consequently, (a) historic data can be used to calculate sample statistics regarding the relevant historical probability distribution, and then (b) these calculations provide statistically reliable estimates of the averages to be drawn from probability distributions that will govern future observations. In other words, the ergodic axiom presumes that statistically reliable estimates of future values can be drawn from past economic data generated by existing economic fundamentals.

7. The underlying Walrasian equations ground out a secular trend of financial market prices that are Pareto-efficient.

8. If asset holders are presumed to be wealth maximisers, then, as I have demonstrated (Davidson, 1997) the claimed differential impact of a transactions tax on short-term vis-a-vis long-term asset holders is mathematically incorrect. Also, see Hicks (1935) and Kahn (1954) who demonstrate that the effects of transactions costs are independent of the holding time of an asset.

9. Note that the term 'rational' only makes sense in an ergodic world.

10. In most empirical studies the ex post moving average of what actually happens in the markets is presumed to be the best estimate of the statistical average (over time) that the fundamentals of an ergodic world have predetermined. Shiller (1981) has demonstrated, however, that the average real rate of return actually obtained in the stock market does not equal the real rate of return that would be expected from 'fundamentals'. The fact that econometric analysis of time series market data always reveals a reversion to the mean is merely, as Basil Moore often says, an arithmetic necessity of calculation of time series moving averages.

11. Puck: 'What fools these mortals be'. (W Shakespeare, A Midsummer Night's Dream).

12. Moreover, there is no reason to have a 
public policy to rescue specific individual agents from the error of their ways.

\section{See The Oxford Dictionary of Quotations} (1959) 2e, Oxford: Oxford U P, p. 35.

14. 'This kind of irrationality is pervasive. Three-fourths of my students believe they are in the top half of the class.' (Stiglitz, 1989 p. 106).

15. Especially durable goods where the expected stream of utility will be yielded at many dates far into the future.

16. Finally, it should be noted that Stiglitz initially argued that it is the rush to be the first to obtain reliable information in a world of asymmetric information that wastes society resources. Nevertheless, in laying the blame for volatility on 'noise traders' who do not try to find reliable information about fundamentals (Stiglitz, 1989 , p. 105), Stiglitz's argument that a transactions tax will reduce the waste of resources seeking to beat the crowd by obtaining reliable information first is irrelevant. A transaction tax, according to Stiglitz, will not affect rational traders seeking reliable information. Rational information seekers in a world of asymmetric information will still have an incentive to beat the rest of the crowd of rational traders in a feeding frenzy on noise traders as long as the tax is less than the hypothesized social return.

17. In associating financial markets with gambling casinos, Stiglitz has failed to realize that casino gambling activities always involve an ergodic system where there are fixed and known time-immutable probability distributions, while in the financial market no such immutable probability distribution need exist.
18. Stiglitz recognizes that market participants may want liquidity, i.e., may want to exchange money for securities or vice versa, and that such financial market exchanges (free of tax) are Pareto efficient (Stiglitz, 1989, p. 104). With asymmetric information, however, those possessing less information about the future are (by definition) trading 'based on incorrect expectations'. Consequently, Stiglitz suggests, it is not obvious that a transactions tax that will make trading on incorrect expectations more expensive lowers social welfare.

19. Keynes $(1936$, p. 241 n.) argues that the 'attribute of liquidity' is by no means independent of the presence of two essential properties, namely that the asset is not reproducible via the employment of labour and it is not substitutable for the producible output of industry.

20. Only in the nonergodic world that is our entrepreneurial economic system, is it sensible to organize complex and lengthy production and exchange processes via the use of nominal contracts (Davidson, 1994). In such a world, the primary function of organized financial markets is to provide liquidity by permitting the resale of assets in an orderly market. Only secondarily do modern superefficient financial markets affect the allocation of new capital amongst industries and to the extent it apportions capital, this distribution is not predetermined by some long-run immutable real economic fundamentals.

21. After reading my paper on rational expectations (Davidson, 1982-83), in a private letter to me (12 February 1983), Hicks wrote 'I have just been reading 
your RE paper... I do like it very much. $I$ have never been through that $\mathrm{RE}$ literature... but I had just enough of it to be put off by the smell of it. You have now rationalized my suspicions, and have shown me that I missed a chance of labelling my own point of view as nonergodic. One needs a name like that to ram a point home.' (Emphasis in original).

22. Or as Sargent suggests 'The people inside the model have much more knowledge about the system they are operating in than is available to the economist or econometrician who is using the model to try to understand their behaviour. In particular, an econometrician faces the problem of estimating probability distributions and laws of motion that the agents in the model are assumed to know. Further, the formal estimation and inference procedures of rational expectations econometrician assumes that the agents in the model already know many of the objects the econometrician is estimating.' (Sargent, 1994, p. 21).

23. In the neoclassical Walrasian microfoundations that Satmuelson synthesized with Keynes' macroeconomics, all producible goods are readily resalable at the equilibrium price vector that encompasses all spot and forward prices determined at the initial instant for all future times. In such an equational system, there is no separation of the market value of underlying real asset and market value of corresponding financial assets - for money and hence nominal financial asset prices are presumed neutral. Liquidity therefore is not a primary function of only financial markets. The $n+m-1$ markets for all new and pre-existing goods provides every good in every time period with liquidity as anyone can be either a buyer or a seller in any of these myriad markets. In an ergodic world, therefore, it is not possible to experience ant drastic reevaluations of the price of assets that re predetermined by real fundamentals.

24. As anyone who observes empty shops, offices, buildings, excess capacity in the auto industry, etc. should readily recognize.

25. Shackle (1972) has pursued the nonergodic basis for asset market valuations to the extreme. Shackle maintained that conventional theory is schizophrenic in that it assumes that there is a stable rate of interest (at least in the long run as a fundamental) while recognizing that an active spot market for bonds requires bull and bear participant interactions where all the participants think the interest rates will change. In essence, Shackle is asking how can there be so much volume in the securities market each day if all participants know that the existing market price reflects the best available valuation of some long-run immutable fundamental.

26. In fact, all markets in liquid assets require the institution of one or more credible 'market-makers' who follow some preannounced rules of the game to assure orderliness in the market. The more orderly the market-maker keeps the market, the less moment-to-moment volatility. It is only when market-makers fail in their responsibility to maintain orderly markets that volatility becomes disruptive and speculation can have real disruptive effects. 
27. In the global economy of the twenty-first century, however, no national monetary authority is likely to always have sufficient credibility under all circumstances. Accordingly, we will require a cooperative international payments system, an International Monetary Clearing Unit system, that has specific rules for a buffer stock policy that assure exchange rate stability (see Davidson, 1997, pp. 680-5).

28. That is why currency boards with reserves equal to the domestic money supply can fix the exchange rate (often at the expense of the domestic credit market).

29. Use of buffer stocks as a public policy solution to stabilize prices over time is as old as the biblical story of Joseph and the Pharaoh's dream of seven fat cows followed by seven lean cows. Joseph the economic forecaster of his day interpreted the Pharaoh's dream as portending seven good harvests where production would be much above normal followed by seven lean harvests where annual production would not provide enough food to go around. Joseph's civilized policy proposal was for the government to accumulate a buffer stock of grain during the good years and release the grain to market, without profit, during the bad years. This would maintain a stable price over the fourteen harvests and avoid sky-rocketing prices and speculative hoarding in the bad years and depressing prices and dumping inventories in the good years. The Bible records that this civilized buffer stock policy was a resounding success.

30. Information on contractual commitments between residents (including banks) of different nations can imply deficits that draw down international reserves to 'low' levels. Given the existing conventional exchange rate systems, calls for 'transparency', i.e., more instant information about contractually committed foreign reserves are the wrong prescription for solving he problem. They are more likely to aggravate it.

31. For example, think about the Federal Reserve fixing the interest rate for more than a decade - until the Accord of 1951 when the market-maker Federal Reserve attempted to induce the Congress and the President to 'tighten their belts' and stop borrowing in order to fight the Korean War.

\section{References}

Arestis P and Sawyer M (1998) 'Keynesian Economic Policies for the New Millennium', The Economic Journal, 108, 181-95.

Bernstein P L (1998) 'Stock Market Risk In A Post Keynesian World' Joumal of Post Keynesian Economics, 21, forthcoming.

Davidson P (1972) Money And The Real World, London: Macmillan

Davidson P (1984) 'Reviving Keynes's Revolution', Journal of Post Keynesian Economics, 6, 561-75.

Davidson P (1991) 'Is Probability Theory Relevant For Uncertainty: A Post Keynesian Perspective' Journal of Economic Perspectives, 5, 29-43.

Davidson P (1994) Post Keynesian Macroeconomic Theory, Cheltenham: Elgar 
Davidson P "Are Grains of Sand in the Wheels of International Finance Sufficient to do the Job when Boulders are often Required?', The Economic Journal, 107, 671-86.

Eichengreen B, Tobin J and Wyplosz C (1995) 'The Case for Sand in the Wheels of International Finance', The Economic Journal, 105, 162-72.

Greenaway D (1995) 'Policy Forum: Sand in the Wheels of International Finance, Editorial Note', The Economic Journal, $105,160-1$.

Hicks J R (1935) 'A Suggestion for Simplifying the Theory of Money', Economica, 2, 1-19.

Hicks J R (1979) Causality in Economics, New York: Basic Books.

Jones C $\quad M$ and Seguin P J (1997) 'Transactions Costs and Price Variability: Evidence from Commission Deregulation', American Economic Review, 87, 728-37.

Kahn R (1954) 'Some Notes on Liquidity Preference', Manchester School, 22, 22745.

Keynes J M (1936) The General Theory of Employment Interest and Money, New York: Harcourt Brace.

Keynes J M (1937) 'The General Theory', Quarterly Journal of Economics, reprinted in Collected Works of John Maynard Keynes, XIV, ed. D Moggridge, London: Macmillan, 1973 All references are to the reprint.

Lucas R E (1981) 'Tobin and Monetarism: A Review Article', Journal of Economic

\section{Literature, 19, 558-67.}

Lucas R E and Sargent T J (1981) Rational Expectations and Econometric Practices, Minneapolis: University of Minnesota Press.

Samuelson P A (1969) 'Classical and Neoclassical Theory' in Monetary Theory, ed. R W Clower, London.

Sargent T J (1993) Bounded Rationality In Macroeconomics, Oxford: Clarendon Press.

Shackle G L S (1972) Epistemics and Economics, Cambridge: Cambridge U P.

Shiller R J (1981) 'Do Stock Markets Move too much to be Justified by Subsequent Changes in Dividends?', American Economic Review, 71, 421-35.

Stiglitz J E (1989) 'Using Tax Policy to Curb Speculative Short-Term Trading', Journal of Financial Services, 3, 101-113.

Summers L H and Summers V P (1989) 'When Financial Markets Work too Well: a Cautious Case for a Securities Transactions Tax', Journal of Financial Services, 3, 163-88.

Tobin J (1974) 'The New Economics One Decade Older', The Janeway Lectures on Historical Economics, Princeton: Princeton U P.

Umlauf S P (1995) 'Transaction Taxes and the Behavior of the Swedish Stock Market', Journal of Financial Economics, 23, 227-40. 